\title{
A bal pitvari méret és funkció echokardiográfiás meghatározásának klinikai jelentősége szívelégtelenségben
}

\author{
Porpáczy Adél, Faludi Réka \\ Pécsi Tudományegyetem, Klinikai Központ, Szívgyógyászati Klinika, Pécs \\ Levelezési cím: \\ Dr. Porpáczy Adél, 7624 Pécs, Ifjúság u. 13. E-mail: porpaczyadel@gmail.com
}

\begin{abstract}
A szívelégtelenség kialakulásának és hemodinamikájának vizsgálata hagyományosan a bal kamra szerkezetére és müködésére összpontosult, a bal pitvart pedig egyszerüen egy passzív „szállító” szívüregnek tekintették, amely csupán továbbítja a vért. Az elmúlt két évtizedben azonban egyre fokozottabb figyelem irányult a bal pitvari struktúra és funkció fontosságára szívelégtelenségben. A bal pitvari paraméterek közül elsőként a volumen került elötérbe, mint a bal kamrai diasztolés diszfunkció súlyosságát és fennállásának időtartamát megbízhatóan jelző indikátor, valamint szívelégtelenségben a kedvezőtlen kardiovaszkuláris kimenetel meghatározója. A közelmúltban azonban nagyobb figyelem fordult a bal pitvari funkció vizsgálatára, amely szívelégtelenségben talán még erőteljesebb diagnosztikus és prognosztikus markerként müködik, mint a jelenlegi ajánlásokban szereplő bal pitvari volumen.
\end{abstract}

Kulcsszavak: bal pitvari volumen, bal pitvari strain, diasztolés funkciózavar, töltőnyomás, szívelégtelenség

\section{Echocardiographic assessment of left atrial size and function in heart failure}

Investigation of the development and hemodinamics of heart failure was traditionally focused on the structure and function of the left ventricle, while left atrium was considered as a passive "transport" chamber, only transmitting blood into the left ventricle. Over the past two decades, however, growing evidence supports the importance of the left atrial structure and function in heart failure. Amongst all left atrial parameters, left atrial volume was reported primarily as a sensitive indicator of the severity and duration of left ventricular diastolic dysfunction and as a predictor of adverse cardiovascular outcomes in heart failure. Nowadays more attention is devoted to the left atrial function, which may serve as an even more powerful diagnostic and prognostic marker in heart failure than left atrial volume, which is included in the current guidelines.

Keywords: left atrial volume, left atrial strain, diastolic dysfunction, filling pressure, heart failure

\section{Bevezetés}

A szívelégtelen betegeknél végzett képalkotó vizsgálatok során a figyelem hosszú ideig a bal kamra (BK) méreteire és a funkciójára összpontosult, míg a bal pitvart (BP) passzív „szállító” szívüregnek tekintették. A noninvazív képalkotó módszerek (mint például a 2- és 3-dimenziós echokardiográfia, a speckle-tracking echokardiográfia és a szív MR-vizsgálat) egyre szélesebb körủ elterjedése tette aztán lehetővé a BP-i struktúra és funkció fontosságának megértését, az utóbbi két évtizedben. Világossá vált, hogy a szívelégtelenség progressziója során a BP is strukturális és funkcionális átalakuláson megy keresztül. Ennek köszön- 
hetően képes a megfelelő kamrai telődést biztosítani a BK-i diasztolés diszfunkció előrehaladott stádiumaiban is, és ezzel egyidejűleg védeni a pulmonalis keringést a megnövekedett hátrafelé ható nyomástól (1). Egyre növekvő számú bizonyíték utal arra, hogy e funkció elvesztése (BP-i diszfunkció) aktívan hozzájárul a szívelégtelenség típusos tüneteinek megjelenéséhez $(2,3)$, és a betegség progressziójához $(4,5)$. Munkánkban a BP morfológiai és funkcionális remodellingjének patofiziológiai és klinikai jelentőségét tekintjük át megtartott és csökkent ejekciós frakcióval járó szívelégtelenségben, felhívva a figyelmet a BP-i paraméterek fontos prognosztikus szerepére is.

\section{Patofiziológai szempontok}

A BP alapvető szerepe a BK-i telődés modulálása. Működése a szívciklus során három fázisból áll. A mitrális billentyű záródása után a kamrai szisztolé során a mitrális anulusz a csúcs felé mozdul, ennek következtében a BP-ben csökken a nyomás. Ez megkönnyíti a vér beáramlását a pulmonalis vénákból, és a $B P$, mint rezervoár fogadja a vért. Kora diasztoléban, a mitrális billentyűk kinyílása után, a BK szívó hatást fejt ki. Ekkor a BP, mint konduit vezeti a vért a $B K$ üregébe a pulmonalis vénákból. A diasztolé késői fázisában a BP aktívan pumpálja a vért a BK üregébe, mintegy 2030\%-kal hozzájárulva a BK-i pulzustérfogathoz. Ebben a fázisban a BP „booster pump”, vagy kontraktilis funkciójáról beszélünk. Mindhárom fázisban szoros az öszszefüggés a BP és a BK müködése között (5).

A diasztolé során a BP közvetlenül ki van téve a BK-i nyomás hatásainak. A diasztolés funkciózavar progressziója és a következményesen emelkedő BK-i töltőnyomás a BP remodellingjéhez vezet. A legszembetünőbb változás a $B P$ méretének növekedése. $A B P$ dilatációja természetesen egyéb okokból is bekövetkezhet (mitrális regurgitáció, pitvarfibrilláció, idősebb életkor, magas perctérfogattal járó állapotok, élsport), de ezek hiányában a BP méretének növekedését leginkább a megnövekedett BK-i töltőnyomás következményének tekinthetjük (1), vagyis a BP-i volumen a tranziensen vagy permanensen emelkedett töltőnyomás érzékeny biomarkerének tekinthető. $P$. S. Douglas híressé vált hasonlata szerint a Dopplerrel nyert paraméterek (E/A, E/e') vizsgálatával csak az éppen aktuális BK-i töltőnyomásra következtethetünk, vagyis ezek az értékek az aktuális vércukorértéknek felelnek meg, míg a pitvar mérete a hosszú távú hatásokat tükrözi, hasonlóan a $\mathrm{HgbA}_{1 \mathrm{c}}$-hez cukorbetegségben (6). A töltönyomás-emelkedés hatására bekövetkező remodelling során a BP funkciója is károsodik, ennek kimutatása azonban sokáig nehézségekbe ütközött.

A BP-re általában mint „szállító” üregre gondolunk, amelynek egyetlen szerepe a vér továbbítása a vena pulmonalisokból a BK felé. A BP ugyanakkor volumen- szenzorként is működik: nátriuretikus peptideket és egyéb neurohormonokat termel a falfeszülés hatására. A BP-i volumen és az aktuális BNP, NT-proBNP-szint közötti szoros korreláció jól ismert (7).

\section{A bal pitvari méretek echokardiográfiás meghatározásának lehetőségei}

Az M-mód vizsgálatok elterjedésének időszakában a paraszternális hosszmetszetben mért anteroposzterior átmérő segítségével adták meg a BP méretét (8). A Framingham-populációban az ily módon becsült BP-méret a pitvarfibrilláció egyik prediktorának bizonyult (9). A módszer jól reprodukálható, ám nem feltétlenül tükrözi a valódi BP-méretet, ugyanis a szomszédos mellkasi képletek korlátozó szerepe miatt a BP dilatációja gyakran nem egyenletes minden dimenzióban, hanem dominálóan szuperoinferior és mediolateralis irányú (10). A 2D echokardiográfia segítségével, csúcsi 4-üregű nézetben mért BP-i area jobb közelítése a $B P$ valós méretének. Ügyelni kell rá, hogy valódi csúcsi nézetben történjen a mérés, ahol a BP legnagyobb metszete látható („foreshortening” kerülendő) (11).

$A$ jelenlegi ajánlások a BP-i volumen mérését preferálják a klinikai gyakorlatban és a kutatásban egyaránt. $A$ legalkalmasabb 2D echokardiográfiás módszerek erre a biplane Simpson és az area-length technika. A mérések mindkét esetben két egymásra merőleges síkban, csúcsi 4-, illetve 2-üregi nézetben történnek. Az így nyert BP-i volumen sokkal szorosabb korrelációt mutat a gold standardnak számító szív MR-eredményekkel, mint az átmérő vagy area értékek (12). Ezt a korrelációt tovább javította a 3D echokardiográfia bevezetése, annak segítségével ugyanis a BP-i volumenérték nem számításokon alapul, hanem valóban megmérhető (11). Ugyanakkor több tanulmány utal arra, hogy mind a 2D, mind a 3D echokardiográfia segítségével nyert BP-i volumenértékek szisztematikusan alacsonyabbak, mint a szív MR vagy CT segítségével mért volumenek (13-15). A testméretek jelentős mértékben befolyásolják a $\mathrm{BP}$ méretét, az egészséges populációban is. Ezért a gyakorlatban a BP-i volumenértékek testfelszínre történő normalizálása ajánlott (BP-i volumenindex) (11). A BP-i volumenindex normáltartománya echokardiográfiával mérve $22 \pm 6 \mathrm{ml} / \mathrm{m}^{2}(5)$.

\section{A bal pitvari funkció echokardiográfiás meghatározásának lehetőségei}

Az elmúlt évtizedek során számos különböző módszert kipróbáltak a BP-i funkció megítélésére, több-kevesebb sikerrel. A mitrális anuluszon szöveti Doppler segítségével mért késődiasztolés hullám (a') például egyértelmúen pitvarfunkciós paraméternek tekinthető és többek között jó korrelációt mutatott az NT-proBNP-értékekkel 


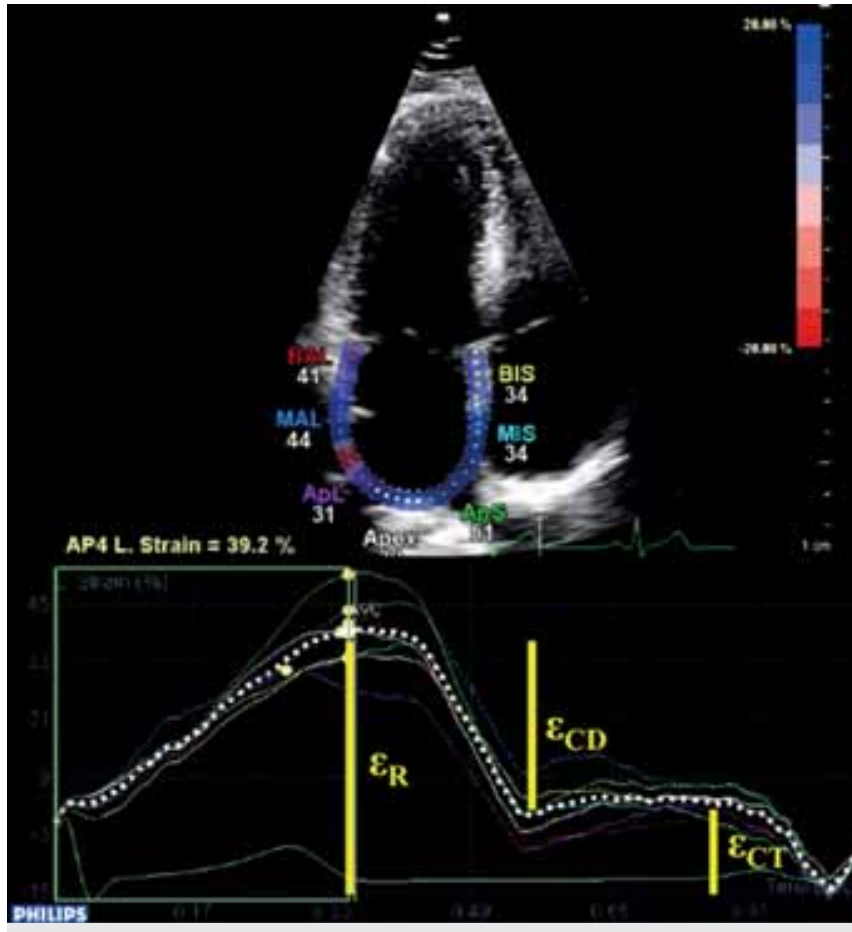

1. ÁBRA. A bal pitvari strain vizsgálata speckle tracking technika segítségével, csúcsi 4-üregi nézetből $\left(\varepsilon_{\mathrm{R}}\right.$ : rezervoár strain, $\varepsilon_{\mathrm{CD}}$ : kontraktilis strain, $\varepsilon_{\mathrm{CT}}$ : konduit strain)

hipertrófiás cardiomyopathiás populációban (16), mégsem vált rutin módszerré.

A BP-i funkciót meghatározhatjuk a maximális $\left(\mathrm{V}_{\max }\right)$, minimális $\left(V_{\min }\right)$ és a P-hullám kezdetekor $\left(V_{p}\right)$ mért BP-i volumenértékekből származtatott paraméterek alapján. A következő fázisos volumenértékek számolhatók ki ezzel a módszerrel: total emptying fraction (TEF): ([ $\mathrm{V}_{\max }$ $\left.\left.-\mathrm{V}_{\min }\right] / \mathrm{V}_{\max }\right) \times 100$; expansion index (EI): $\left(\left[\mathrm{V}_{\max }-\mathrm{V}_{\min }\right] /\right.$ $\left.\mathrm{V}_{\text {min }}\right) \times 100$; active emptying fraction $(\mathrm{AEF}):\left(\left[\mathrm{V}_{\mathrm{p}}-\mathrm{V}_{\text {min }}\right] /\right.$ $\left.V_{p}\right) \times 100$; passive emptying fraction $(P E F):\left(\left[V_{\max }-V_{p}\right] /\right.$ $\left.V_{\max }\right) \times 100$. A TEF és El a rezervoár, az AEF a kontraktilis, míg a PEF a konduit funkciót tükrözi (17).

Az utóbbi években azonban egyre nagyobb teret kapott a BP-i funkció vizsgálatában egy új módszer, a speckle-tracking echokardiográfia segítségével mért BP-i strain $(18,19)$. A BP-re fókuszált csúcsi 4- és 2-üregú felvételek offline analízise során kapjuk meg a strain görbét, amiről a rezervoár, kontraktilis és konduit strain értékek leolvashatók (20) (1. ábra). A BP-i strain az irodalmi adatok szerint jól korrelál a szív MR-vizsgálattal meghatározott BP-i fibrózis mértékével (21), valamint szövettani minták alapján összefüggést mutat a BP-i intersticiális fibrózis mértékével súlyos mitrális billentyüelégtelenség esetén (22).

A BP-i mechanika további paramétere a BP-i stiffness, ami az E/e' és a pitvari rezervoár strain arányaként számolható ki. Ez a szöveti Doppler és speckle-tracking echokardiográfia alapú paraméter jelzi azt a nyomást, amely a pitvar térfogatának egységnyi növeléséhez szükséges (23). Egy pitvarfibrilláló betegek körében végzett vizsgálat szerint a BP-i stiffness erősebb korrelációt mutat a $\mathrm{BP}$-i fibrózis - elektroanatómiai térképezés segítségével meghatározott - mértékével, mint a pitvari strain paraméterek (24).

\section{A bal pitvari volumen és funkció szívelégtelenségben}

A mindennapi gyakorlatban a BK-i diasztolés funkció és töltőnyomás megítélésre az echokardiográfiát használjuk. A BK-i diasztolés funkció vizsgálatával foglalkozó jelenlegi ASE/EACVI ajánlás egyik alappillérét az E/e' képezi, ami közismerten korrelációt mutat a BK-i töltőnyomással (25-27). Számos friss tanulmány ugyanakkor megkérdőjelezi az E/e' diagnosztikus erejét megtartott ejekciós frakcióval járó szívelégtelenségben (HFpEF-ben) szenvedő vagy abból a szempontból magas rizikójú betegpopulációban (28-31). Így napjainkban egyre nyilvánvalóbb, hogy az emelkedett BK-i töltőnyomás egyértelmú felismeréséhez az E/e' mellett további echokardiográfiás paraméterek is szükségesek. Az ASE/EACVI ajánlás diagnosztikus algoritmusában a maximális BP-i volumenindex szerepel, mint a tartósan vagy visszatérően emelkedett BP-i töltőnyomás megbízható biomarkere (27). A $34 \mathrm{ml} / \mathrm{m}^{2}$-es BP-i volumenindex-érték (normálérték+2 SD) szerepel cut-offként, ami egy erősen specifikus, de kevéssé szenzitív értéknek tekinthető az emelkedett BP-i nyomás kimutatására vonatkozóan (32). Az alternatív diagnosztikus algoritmusokban azonban említésre kerül a $28 \mathrm{ml} / \mathrm{m}^{2}$-es (normálérték+1SD) érték is, ami lényegesen szenzitívebb cut-offnak tekinthető $(32,33)$. Meg kell jegyezni, hogy a diasztolés funkciózavar korai fázisában (károsodott relaxáció) a BP-i volumen nem, vagy csak kismértékben emelkedett. Szignifikáns BP-i dilatáció gyakran csak előrehaladott diasztolés funkciózavar esetén (pszeudonormális, illetve restriktív mitralis beáramlási görbe) figyelhető meg (34). Bár a maximális BP-i volumenindex diagnosztikus szerepét kiterjedt irodalom támogatja, adatok találhatók arra nézve is, hogy a minimális BP-i volumenindex és a BK-i töltőnyomás közötti korreláció még ennél is szorosabb lehet (35).

Az utóbbi években több munkacsoport is igazolta, hogy a BP-i funkció károsodása megelőzi a méretbeli változásokat, vagyis a pitvari strain értékek változása már a diasztolés funkciózavar korai stádiumában is jelen van (36-38). A BP kulcsszerepet játszik a BK-i telődés megőrzésében. A diasztolés diszfunkció korai stádiumában a BP-i preload növekedésével a Frank-Starling-mechanizmusnak megfelelően a BP kontraktilitása megnő, amellyel kezdetben képes kompenzálni a károsodott BK-i relaxációt. Ez a kompenzatórikus mechanizmus a kamrai diasztolés funkciózavar további progressziójával kimerül $(39,40)$. A BP-i strain vizsgálatával ezek a folyamatok echokardiográfiával is igazolhatóak: a rezervoár és konduit funkció már a károsodott relaxá- 
1. TÁBLÁZAT. A bal pitvar (BP) méretében és funkciójában bekövetkező változások a bal kamrai diasztolés funkciózavar progreszsziójával párhuzamosan (E/A, E/e' és volumenértékek az ASE/EACVI ajánlás alapján (27)

\begin{tabular}{|l|c|c|c|c|}
\hline & Normális & Károsodott relaxáció & Pszeudonormalizáció & Restriktív zavar \\
\hline Mitralis E/A & $\geq 0,8$ & $<0,8$ & $0,8-2$ & $\geq 2$ \\
\hline Mitralis E/e' & $<10$ & $<10$ & $10-14$ & $>14$ \\
\hline BP-i volumenindex & $\leftrightarrow$ & $\leftrightarrow(\uparrow)$ & $\uparrow$ & $\uparrow \uparrow$ \\
\hline BP-i rezervoár strain & $\leftrightarrow$ & $\downarrow$ & $\downarrow \downarrow$ & $\downarrow \downarrow$ \\
\hline BP-i kontraktilis strain & $\leftrightarrow$ & $\uparrow$ & $\downarrow$ & $\downarrow \downarrow$ \\
\hline BP-i konduit strain & $\leftrightarrow$ & $\downarrow$ & $\downarrow \downarrow$ & $\downarrow \downarrow \downarrow$ \\
\hline
\end{tabular}

ció fázisában csökkent, míg a kontraktilis funkció javulása észlelhető az egészséges személyekhez képest. A diasztolés funkciózavar előrehaladottabb stádiumaiban a rezervoár, konduit és kontraktilis strain egyaránt károsodottnak mutatkozik $(37,38,40)$ (1. táblázat).

Az egészséges populációhoz képest mind a csökkent ejekciós frakcióval járó szívelégtelenségben (HFrEF), mind HFpEF-ben károsodott BP-i funkció igazolható, bár a BP-i remodelláció pontos patomechanizmusában alapvető különbségek feltételezhetők a két kórkép esetén: míg HFrEF-ben inkább excentrikus a BP-i remodelling, addig HFpEF-betegek körében a BP-i stiffness emelkedése figyelhető meg $(41,42)$.

Mint korábban említettük, a BK-i töltőnyomás-emelkedés egyértelmü diagnózisához több echokardiográfiás paraméter egyidejü alkalmazása szükséges. Több nemrégiben napvilágot látott kutatás alapján a BP-i rezervoár strain - felülmúlva a $\mathrm{BP}$-i volumenindex diagnosztikus erejét - erősebb korrelációt mutat mind az invazívan mért BK-i töltőnyomással, mind az NT-proBNP-szinttel szívelégtelenségben (40, 43, 44). Ugyanakkor munkacsoportunk nemrégiben igazolta, hogy szisztémás szklerózisban a BP-i stiffness az emelkedett NT-proBNP-szint erősebb prediktora, mint a BP-i volumenindex vagy a BP-i rezervoár strain (45). Bár a későbbiekben még invazív validációs vizsgálatok szükségesek, ez az eredmény arra utal, hogy a BP-i stiffness használata tovább javíthatja a noninvazív echokardiográfiás vizsgálatok diagnosztikus precizitását HFpEF szempontjából magas rizikójú betegcsoportokban (45).

A fentiek alapján elmondható, hogy a BP funkciója változást mutat már a diasztolés funkciózavar korai fázisában, majd HFpEF-ben és HFrEF-ben egyaránt, jelentősen befolyásolva a kórlefolyást. A pitvarfibrilláció a BP-i remodelling egyik legkritikusabb következménye: a pitvarfal feszülése és fibrotikus átalakulása az elektromos vezetési viszonyok kedvezőtlen átalakulását is eredményezi. Pitvarfibrillációban pedig elvész a BP-kamratelődést támogató hatása, ami manifeszt szívelégtelenség kialakulásához vezethet, vagy tovább rontja a szívelégtelen betegek állapotát (1). HFrEF-ben, köszönhetően a számos, jelentős effektivitással bíró farmakológiai és nonfarmakológiai terápiás lehetőségeknek, a betegség hosszú távú kimenetele az utób- bi időben javult. Ezzel szemben HFpEF-ben továbbra sem sikerül áttörő, a morbiditásra és mortalitásra is kedvezően ható kezelési stratégiát kiépíteni. Mivel a BP funkciója igen érzékeny biomarkere a betegek állapotának HFpEF-ben, a későbbi study-k terápiás végpontjait érdemes lenne a BP vizsgálata köré is strukturálni. Vagyis a BP-i strain és stiffness paraméterek alkalmazása nemcsak diagnosztikus előnyökkel járhat, hanem az új terápiás lehetőségek hatékonyságának monitorozásában is kiemelkedő jelentőséggel bírhatnak (1).

\section{A bal pitvar prognosztikus szerepe szívelégtelenségben}

Tsang és munkatársai a kétezres években igazolták, hogy a maximális BP-i volumen erősebb prediktora a kardiovaszkuláris eseményeknek, mint a BP-i átmérő és area értékek (46). Számos további kutatás igazolta aztán, hogy a maximális BP-i volumen érzékeny prediktora a pitvarfibrilláció és a stroke kialakulásának, valamint a mortalitásnak. Idős betegeknél a BP dilatációja kétszeres rizikót jelent a szívelégtelenség kialakulására a BK-i szisztolés funkciótól függetlenül (47). Nagyszámú esettanulmány és metaanalízis alapján HFrEF-ben szenvedő betegpopulációban a BP mérete képes előre jelezni a kedvezőtlen kimenetelt függetlenül az ejekciós frakciótól és a NYHA-stádiumtól (48-50). Hasonlóképpen, a HFpEF-betegekben a BP megnagyobbodása egyértelműen korrelál a betegség súlyosságával és a kedvezőtlen kardiovaszkuláris eseményekkel, valamint megnövekedett mortalitással társul (51-53). A HFpEF-es vagy arra magas rizikójú szisztémás szklerózisban szenvedő betegekben a BP-i volumenindex szintén a halálozás erős prediktorának bizonyult (54). Emellett a BP-i volumenindex a terhelési intolerancia egyik legerősebb független jelzője HFpEF-ben (55). Habár a BP-i funkció paramétereivel kapcsolatban egyelőre kevesebb vizsgálat áll rendelkezésünkre, friss kutatások szerint a BP-i rezervoár strain a BP-i volumenindexnél is jobb prognosztikus paraméternek ígérkezik a kardiovaszkuláris kimenetel szempontjából $(56,57)$. HFpEF-ben a károsodott BP-i funkció független prediktora a rehospitalizációnak (4), emellett a BP-i rezervoár strain szignifikáns korrelációt mutat a funkcionális kapacitással $(58,59)$. 


\section{Következtetések}

\section{A BP mérete nő, míg funkciója károsodik a diasztolés diszfunkció progressziójával párhuzamosan, fontos szerepet játszva mind a HFpEF, mind a HFrEF kórle- folyásában. A BP méretének, és még inkább a funkció- jának átfogó értékelése fontos szerepet játszhat nem- csak a szívelégtelenség diagnosztikájában, hanem a kórkép súlyosságának és prognózisának megítélésé- ben is.}

\section{Irodalom}

1. Cameli M, Mandoli GE, Mondillo S. Left atrium: the last bulwark before overt heart failure. Heart Fail Rev 2017; 22(1): 123-31. DOI: 10.1007/s10741-016-9589-9

2. Donal E, Raud-Raynier P, Place C de, et al. Resting echocardiographic assessments of left atrial function and filling pressure interest in the understanding of exercise capacity in patients with chronic congestive heart failure. J Am Soc Echocardiogr 2008; 21(6): 703 10. DOI: $10.1016 /$ j.echo.2007.10.002

3. Melenovsky V, Borlaug BA, Rosen B, et al. Cardiovascular features of heart failure with preserved ejection fraction versus nonfailing hypertensive left ventricular hypertrophy in the urban Baltimore community: the role of atrial remodeling/dysfunction. J Am Coll Cardiol 2007; 49(2): 198-207. DOI: 10.1016/j.jacc.2006.08.050

4. Welles CC, Ku IA, Kwan DM, et al. Left atrial function predicts heart failure hospitalization in subjects with preserved ejection fraction and coronary heart disease: longitudinal data from the Heart and Soul Study. J Am Coll Cardiol 2012; 59(7): 673-80. DOI: 10.1016/j. jacc.2011.11.012

5. Hoit BD. Left atrial size and function: role in prognosis. J Am Coll Cardiol 2014; 63(6): 493-505. DOI: 10.1016/j.jacc.2013.10.055

6. Douglas PS. The left atrium. J Am Coll Cardiol 2003; 42(7): 1206 7. DOI: $10.1016 / \mathrm{S} 0735-1097(03) 00956-2$

7. Lim TK, Ashrafian H, Dwivedi G, et al. Increased left atrial volume index is an independent predictor of raised serum natriuretic peptide in patients with suspected heart failure but normal left ventricular ejection fraction: Implication for diagnosis of diastolic heart failure. Eur J Heart Fail 2006; 8(1): 38-45. DOI: 10.1016/j.ejheart.2005.05.008

8. Sahn DJ, DeMaria A, Kisslo J et al. Recommendations regarding quantitation in M-mode echocardiography: results of a survey of echocardiographic measurements. Circulation 1978; 58(6): 1072-83. 9. Vaziri SM, Larson MG, Benjamin EJ, et al. Echocardiographic predictors of nonrheumatic atrial fibrillation. The Framingham Heart Study. Circulation 1994; 89(2): 724-30.

10. Lester SJ, Ryan EW, Schiller NB, et al. Best method in clinica practice and in research studies to determine left atrial size. Am J Cardiol 1999; 84(7): 829-32.

11. Lang RM, Badano LP, Mor-Avi V, et al. Recommendations for cardiac chamber quantification by echocardiography in adults: an update from the American Society of Echocardiography and the European Association of Cardiovascular Imaging. Eur Heart J Cardiovasc Imaging 2015; 16(3): 233-70. DOI: 10.1093/ehjci/jev014

12. Rodevan $O$, Bjornerheim $R$, Ljosland $M$, et al. Left atrial volumes assessed by three- and two-dimensional echocardiography compared to MRI estimates. Int J Card Imaging 1999; 15(5): 397-410.

13. Artang R, Migrino RQ, Harmann L, et al. Left atrial volume measurement with automated border detection by 3-dimensional echocardiography: comparison with Magnetic Resonance Imaging. Cardiovasc Ultrasound 2009; 7: 16. DOI: 10.1186/1476-7120-7-16

14. Miyasaka $\mathrm{Y}$, Tsujimoto $\mathrm{S}$, Maeba $\mathrm{H}$, et al. Left atrial volume by real-time three-dimensional echocardiography: validation by 64 -sli- ce multidetector computed tomography. J Am Soc Echocardiogr 2011; 24(6): 680-6. DOI: 10.1016/j.echo.2011.03.009

15. Gweon HM, Kim SJ, Kim TH, et al. Evaluation of left atrial volumes using multidetector computed tomography: comparison with echocardiography. Korean J Radiol 2010; 11(3): 286-94. DOI: 10.3348/kjr.2010.11.3.286

16. Faludi $R$, Tóth $L$, Pótó $L$, et al. A B típusú natriureticus peptid (NT-proBNP) szint és a diastolés funkciót jellemző hagyományos és szöveti Doppler-echokardiográfiás paraméterek kapcsolata hypertrophiás cardiomyopathiában szenvedő betegekben. Orvosi Hetilap 2005; 146(1): 23-6.

17. To ACY, Flamm SD, Marwick TH, et al. Clinical utility of multimodality LA imaging: assessment of size, function, and structure. JACC Cardiovasc Imaging 2011; 4(7): 788-98. DOI: 10.1016/j. jcmg.2011.02.018

18. Vieira MJ, Teixeira R, Gonçalves L, et al. Left atrial mechanics: echocardiographic assessment and clinical implications. J Am Soc Echocardiogr 2014; 27(5): 463-78. DOI: 10.1016/j.echo.2014.01.021 19. Cameli M, Caputo M, Mondillo S, et al. Feasibility and reference values of left atrial longitudinal strain imaging by two-dimensional speckle tracking. Cardiovasc Ultrasound 2009; 7: 6. DOI: 10.1186/1476-7120-7-6

20. Badano LP, Kolias TJ, Muraru D, et al. Standardization of left atrial, right ventricular, and right atrial deformation imaging using two-dimensional speckle tracking echocardiography: a consensus document of the EACVI/ASE/Industry Task Force to standardize deformation imaging. Eur Heart J Cardiovasc Imaging 2018; 19(6): 591-600. DOI: 10.1093/ehjci/jey042

21. Kuppahally SS, Akoum N, Burgon NS, et al. Left atrial strain and strain rate in patients with paroxysmal and persistent atrial fibrillation: relationship to left atrial structural remodeling detected by delayed-enhancement MRI. Circ Cardiovasc Imaging 2010; 3(3): 231 9. DOI: $10.1161 /$ CIRCIMAGING.109.865683

22. Her AY, Choi EY, Shim CY, et al. Prediction of left atrial fibrosis with speckle tracking echocardiography in mitral valve disease: a comparative study with histopathology. Korean Circ J 2012; 42(5): 311-8. DOI: 10.4070/kcj.2012.42.5.311

23. Kurt M, Wang J, Torre-Amione G, et al. Left atrial function in diastolic heart failure. Circ Cardiovasc Imaging 2009; 2(1): 10-5. DOI: 10.1161/CIRCIMAGING.108.813071

24. Pilichowska-Paszkiet E, Baran J, Sygitowicz G, et al. Noninvasive assessment of left atrial fibrosis. Correlation between echocardiography, biomarkers, and electroanatomical mapping. Echocardiography 2018; 35(9): 1326-34. DOI: 10.1111/echo.14043

25. Paulus WJ, Tschöpe C, Sanderson JE, et al. How to diagnose diastolic heart failure: a consensus statement on the diagnosis of heart failure with normal left ventricular ejection fraction by the Heart Failure and Echocardiography Associations of the European Society of Cardiology. Eur Heart J 2007; 28(20): 2539-50. DOI: 10.1093/ eurheartj/ehm037

26. Ponikowski P, Voors AA, Anker SD, et al. 2016 ESC Guidelines for the diagnosis and treatment of acute and chronic heart failure: The Task Force for the diagnosis and treatment of acute and chronic heart failure of the European Society of Cardiology (ESC)Developed with the special contribution of the Heart Failure Association (HFA) of the ESC. Eur Heart J 2016; 37(27): 2129-200. DOI: 10.1093/eurheartj/ehw128

27. Nagueh SF, Smiseth $\mathrm{OA}$, Appleton $\mathrm{CP}$, et al. Recommendations for the evaluation of left ventricular diastolic function by echocardiography: An update from the American Society of Echocardiography and the European Association of Cardiovascular Imaging. J Am Soc Echocardiogr 2016; 29(4): 277-314. DOI: 10.1016/j. echo.2016.01.011

28. Santos M, Rivero J, McCullough SD et al. E/e' Ratio in Patients With Unexplained Dyspnea: Lack of Accuracy in Estimating Left 
Ventricular Filling Pressure. Circ Heart Fail 2015; 8(4): 749-56. DOI: 10.1161/CIRCHEARTFAILURE.115.002161

29. Sharifov OF, Schiros CG, Aban I, et al. Diagnostic Accuracy of Tissue Doppler Index E/e' for Evaluating Left Ventricular Filling Pressure and Diastolic Dysfunction/Heart Failure With Preserved Ejection Fraction: A Systematic Review and Meta-Analysis. J Am Heart Assoc 2016; 5(1). DOI: 10.1161/JAHA.115.002530

30. Lancellotti P, Galderisi M, Edvardsen T, et al. Echo-Doppler estimation of left ventricular filling pressure: results of the multicentre EACVI Euro-Filling study. Eur Heart J Cardiovasc Imaging 2017; 18(9): 961-8. DOI: 10.1093/ehjci/jex067

31. Obokata M, Borlaug BA. The strengths and limitations of E/e' in heart failure with preserved ejection fraction. Eur J Heart Fail 2018; 20(9): 1312-4. DOI: 10.1002/ejhf.1250

32. Shuai X-X, Chen Y-Y, Lu Y-X, et al. Diagnosis of heart failure with preserved ejection fraction: which parameters and diagnostic strategies are more valuable? Eur J Heart Fail 2011; 13(7): 737-45. DOI: 10.1093/eurjhf/hfr053

33. Mitter SS, Shah SJ, Thomas JD. A Test in Context: E/A and E/e to Assess Diastolic Dysfunction and LV Filling Pressure. J Am Coll Cardiol 2017; 69(11): 1451-64. DOI: 10.1016/j.jacc.2016.12.037

34. Pritchett AM, Mahoney DW, Jacobsen SJ, et al. Diastolic dysfunction and left atrial volume: a population-based study. J Am Coll Cardiol 2005; 45(1): 87-92. DOI: 10.1016/j.jacc.2004.09.054

35. Appleton CP, Galloway JM, Gonzalez MS, et al. Estimation of left ventricular filling pressures using two-dimensional and Doppler echocardiography in adult patients with cardiac disease. Additional value of analyzing left atrial size, left atrial ejection fraction and the difference in duration of pulmonary venous and mitral flow velocity at atrial contraction. J Am Coll Cardiol 1993; 22(7): 1972-82.

36. Mondillo S, Cameli M, Caputo ML, et al. Early detection of left atrial strain abnormalities by speckle-tracking in hypertensive and diabetic patients with normal left atrial size. J Am Soc Echocardiogr 2011; 24(8): 898-908. DOI: 10.1016/j.echo.2011.04.014

37. Porpáczy A, Nógrádi Á, Kehl D, et al. Impairment of left atrial mechanics is an early sign of myocardial involvement in systemic sclerosis. J Card Fail 2018; 24(4): 234-42. DOI: 10.1016/j.cardfail.2018.02.012

38. Brecht A, Oertelt-Prigione $S$, Seeland $U$, et al. Left atrial function in preclinical diastolic dysfunction: Two-dimensional speckle-tracking echocardiography-derived results from the BEFRI trial. J Am Soc Echocardiogr 2016; 29(8): 750-8. DOI: 10.1016/j. echo.2016.03.013

39. Prioli A, Marino P, Lanzoni L, et al. Increasing degrees of left ventricular filling impairment modulate left atrial function in humans. Am J Cardiol 1998; 82(6): 756-61.

40. Singh A, Addetia K, Maffessanti F, et al. LA Strain for categorization of LV diastolic dysfunction. JACC Cardiovasc Imaging 2017; 10(7): 735-43. DOI: 10.1016/j.jcmg.2016.08.014

41. Melenovsky V, Hwang S-J, Redfield MM, et al. Left atrial remodeling and function in advanced heart failure with preserved or reduced ejection fraction. Circ Heart Fail 2015; 8(2): 295-303. DOI: 10.1161/CIRCHEARTFAILURE.114.001667

42. Triposkiadis F, Pieske B, Butler J, et al. Global left atrial failure in heart failure. Eur J Heart Fail 2016; 18(11): 1307-20. DOI: 10.1002/ ejhf.645

43. Kurt M, Tanboga IH, Aksakal E, et al. Relation of left ventricular end-diastolic pressure and $\mathrm{N}$-terminal pro-brain natriuretic peptide level with left atrial deformation parameters. Eur Heart J Cardiovasc Imaging 2012; 13(6): 524-30. DOI: 10.1093/ejechocard/jer283

44. Cameli M, Sparla S, Losito M, et al. Correlation of left atrial strain and Doppler measurements with invasive measurement of left ventricular end-diastolic pressure in patients stratified for different values of ejection fraction. Echocardiography 2016; 33(3): 398-405. DOI: 10.1007/s10741-015-9520-9

45. Porpáczy A, Nógrádi Á, Vértes $V$, et al. Left atrial stiffness is superior to volume and strain parameters in predicting elevated NT-proBNP levels in systemic sclerosis patients. Int J Cardiovasc Imaging 2019. DOI: 10.1007/s10554-019-01621-w

46. Tsang TSM, Abhayaratna WP, Barnes ME, et al. Prediction of cardiovascular outcomes with left atrial size: is volume superior to area or diameter? J Am Coll Cardiol 2006; 47(5): 1018-23. DOI: 10.1016/j.jacc.2005.08.077

47. Takemoto Y, Barnes ME, Seward JB, et al. Usefulness of left atrial volume in predicting first congestive heart failure in patients $>$ or $=65$ years of age with well-preserved left ventricular systolic function. Am J Cardiol 2005; 96(6): 832-6. DOI: 10.1016/j.amjcard.2005.05.031 48. Quiñones MA, Greenberg BH, Kopelen HA, et al. Echocardiographic predictors of clinical outcome in patients with left ventricular dysfunction enrolled in the SOLVD registry and trials: significance of left ventricular hypertrophy. Studies of Left Ventricular Dysfunction. J Am Coll Cardiol 2000; 35(5): 1237-44.

49. Rossi A, Temporelli PL, Quintana M, et al. Independent relationship of left atrial size and mortality in patients with heart failure: an individual patient meta-analysis of longitudinal data (MeRGE Heart Failure). Eur J Heart Fail 2009; 11(10): 929-36. DOI: 10.1093/ eurjhf/hfp112

50. Carluccio E, Biagioli $P$, Mengoni $A$, et al. Left atrial reservoir function and outcome in heart failure with reduced ejection fraction. Circ Cardiovasc Imaging 2018; 11(11): e007696. DOI: 10.1161/CIRCIMAGING.118.007696

51. Rossi A, Gheorghiade M, Triposkiadis F, et al. Left atrium in heart failure with preserved ejection fraction. Circ Heart Fail 2014; 7(6): 1042-9. DOI: 10.1161/CIRCHEARTFAILURE.114.001276

52. Zile MR, Gottdiener JS, Hetzel SJ, et al. Prevalence and significance of alterations in cardiac structure and function in patients with heart failure and a preserved ejection fraction. Circulation 2011; 124(23): 2491-501. DOI: 10.1161/CIRCULATIONAHA.110.011031

53. Kaneko H, Koike A, Senoo K, et al. Role of cardiopulmonary dysfunction and left atrial remodeling in development of acute decompensated heart failure in chronic heart failure with preserved left ventricular ejection fraction. J Cardiol 2012; 59(3): 359-65. DOI: 10.1016/j.jjcc.2012.01.004

54. Faludi R, Költő G, Bartos B, et al. Five-year follow-up of left ventricular diastolic function in systemic sclerosis patients: determinants of mortality and disease progression. Semin Arthritis Rheum 2014; 44(2): 220-7. DOI: 10.1016/j.semarthrit.2014.04.001

55. Ratanasit N, Karaketklang K, Chirakarnjanakorn S, et al. Left atrial volume as an independent predictor of exercise capacity in patients with isolated diastolic dysfunction presented with exertional dyspnea. Cardiovasc Ultrasound 2014; 12: 19. DOI: 10.1186/14767120-12-19

56. Cameli M, Lisi M, Focardi M, et al. Left atrial deformation analysis by speckle tracking echocardiography for prediction of cardiovascular outcomes. 2012; 110(2): 264-9. DOI: 10.1016/j.amjcard.2012.03.022

57. Freed BH, Daruwalla V, Cheng JY, et al. Prognostic utility and clinical significance of cardiac mechanics in heart failure with preserved ejection fraction: Importance of left atrial strain. Circ Cardiovasc Imaging 2016; 9(3). DOI: 10.1161/CIRCIMAGING.115.003754

58. Morris DA, Gailani M, Vaz Pérez A, et al. Left atrial systolic and diastolic dysfunction in heart failure with normal left ventricular ejection fraction. J Am Soc Echocardiogr 2011; 24(6): 651-62. DOI: 10.1016/j.echo.2011.02.004

59. Roşca M, Popescu BA, Beladan CC, et al. Left atrial dysfunction as a correlate of heart failure symptoms in hypertrophic cardiomyopathy. J Am Soc Echocardiogr 2010; 23(10): 1090-8. DOI: 10.1016/j. echo.2010.07.016 